\title{
Intelligent conditioning for the intensive production of tilapia in the southern zone of the State of Mexico
}

\section{Acondicionamiento inteligente para la producción intensiva de tilapia en la zona Sur del Estado de México}

\author{
DE ANDA-LÓPEZ, Rosa María†*, AGUIRRE-ARANDA, Rodolfo, SÁNCHES-SALINAS, Agripín \\ and JARAMILLO-PLATA, Horacio
}

Universidad Tecnológica del Sur del Estado de México

ID $1^{\text {st }}$ Author: Rosa María, De Anda-López, ORC ID: 0000-0003-3326-252, Researcher ID Thomson: C-7103-2019, CVU CONACYT ID: 596793

ID $1^{\text {st }}$ Coauthor: Rodolfo, Aguirre-Aranda / ORC ID: 0000-0002-2968-9732, CVU CONACYT ID: 990003

ID $2^{\text {nd }}$ Coauthor: Agripín, Sánches-Salinas

ID $3^{\text {rd }}$ Coauthor: Horacio, Jaramillo-Plata

DOI: $10.35429 /$ JNAS.2019.18.6.15.23

Received March 21, 2019; Accepted June 30, 2019

\begin{abstract}
Fish farming is a fundamental sector of the economy for several communities. Traditionally, the processes inherent to this activity, such as the feeding of the fish, the replacement of water, the control of temperature, the level of ammonium, are carried out manually and empirically; However, in recent years they have begun to incorporate technological tools for their automation. In the present work we seek to integrate intelligent and separate control systems that exist in the market to generate a single intelligent control system, with the ability to control temperature, ammonia, water clarity, food, in such a way that is presented as a flexible and integrated production process, that meets the requirements of aquaculture health, this system should provide, to small producers in the southern area of the State of Mexico, the certainty that your product meets specifications and standards for human consumption. With this study new opportunities for the application of technologies, especially those of low cost, are envisaged, so that they are accessible to the greatest number of fish farmers and their use guarantees the improvement in the processes carried out. It also highlights the importance that the use of alternative energies can have, to make the most of natural resources and minimize the environmental impact.
\end{abstract}

Intelligent system, Systems automation, Fish farming

\begin{abstract}
Resumen
La piscicultura es un sector de la economía fundamental para varias comunidades. Tradicionalmente, los procesos inherentes a esta actividad, como la alimentación de los peces, el recambio de agua, el control de la temperatura, el nivel de amonio, se realiza de forma manual y empírica; no obstante, en los últimos años se han comenzado a incorporar herramientas tecnológicas para su automatización. En el presente trabajo se busca integrar sistemas inteligentes y por separado de control que existen en el mercado para generar un solo sistema inteligente de control, con la capacidad de controlar la temperatura, el amonio, la claridad del agua, la alimentación, de tal forma que se presente como un proceso flexible e integrado de producción, que cumpla con los requisitos de sanidad acuícola, este sistema deberá de proporcionar, a los pequeños productores de la zona Sur del Estado de México, la certeza de que su producto cumple con especificaciones y normas para el consumo humano. Con este estudio se vislumbran nuevas oportunidades de aplicación de tecnologías, en especial aquellas de bajo costo, para que sean accesibles a la mayor cantidad de piscicultores y su uso garantice la mejora en los procesos realizados. También se resalta la importancia que puede tener el uso de energías alternativas, para aprovechar al máximo los recursos naturales y minimizar el impacto ambiental.
\end{abstract}

Sistema inteligente, Automatización de sistemas, Psicultura

Citation: DE ANDA-LÓPEZ, Rosa María, AGUIRRE-ARANDA, Rodolfo, SÁNCHES-SALINAS, Agripín and JARAMILLO-PLATA, Horacio. Intelligent conditioning for the intensive production of tilapia in the southern zone of the State of Mexico. Journal of Natural and Agricultural Sciences. 2019, 6-18: 15-23

*Correspondence to Author (rossyanda@gmail.com)

$\dagger$ Researcher contributing first author 


\section{Introduction}

Worldwide, the production of fish in ponds for human consumption plays an important role both for the food autonomy of the communities and for their economic sustainability (Merino, et al., 2013). For example, in countries such as Colombia there are several regions that historically specialize in the reproduction and consumption of species and base their activities on this work (Esquivel, et al., 2014).

There is a global trend towards the intensification of aquaculture systems, however a large part of the world's production is still obtained from small-scale "rural type" aquaculture and extensive systems. The real potential of the activity is found in small- and medium-scale aquaculture, which depends primarily on the participation of the government in its development (Ponce, et al., 2006).

The term rural aquaculture has been used to distinguish from other production systems, the cultivation of aquatic organisms by family groups through extensive or semi-intensive breeding systems for self-consumption or partial commercialization (Edward and Demaine, 1997). The use of the denomination ARPE (Rural Aquaculture in Small Scale) arises in 1999 in the Rural Aquaculture Workshop, organized by FAO and the Catholic University of Temuco, Chile (FAO, 2002).

Studies carried out in various regions of Mexico have suggested that rural tilapia aquaculture is a production alternative capable of attenuating demand and reducing pressure on natural resources. The production of tilapia is important as an alternative in the generation of jobs, the roots in the communities and the production of food of high nutritional quality for the human being (Amador del Ángel, et al., 2006).

Research has been found that allows us to know that work has been done constantly and continuously to improve the environmental conditions of the fish that are cultivated, depending on the species to be planted, but these works are focused in a very timely manner on the large factories that they produce very large quantities of products, and do not focus on the small producers that are the ones that really represent the sustenance and economy of the country.
Currently, in areas of our country, the cultivation of tilapia is carried out without any control producing diseases caused by some factors, first by not having an acceptable water exchange in the production tanks, so it is important to maintain the habitat of the fish suitable for its best development with water exchanges, maintaining adequate oxygen levels, temperature is also important because it directly affects the environment in which it develops (Lagos \& Mera, 2015).

In the State of Mexico there is a great tradition in the consumption of sweet-fish fish such as charales, white fish and juiles. This has been increased by the introduction of allochthonous fish, such as Chinese carps and tilapia, which have reached 3,311 tons and 400 tons respectively (SEMARNAP, 2007).

In this order of ideas, it is important to highlight that in our country, in the topic of tilapia farming, aquaculture health occupies a very important place, according to research carried out on this subject, diseases are the cause of important economic losses limiting the production and product quality and are also responsible for massive mortalities. Faced with this situation, studies are underway to automate tilapia farms, in such a way that production increases and the economy of the producers improves.

It is important to highlight that, despite being in the era of the use of ICTs, of the technological revolution, there are often fish farms that perform artisanal tasks and do not have technological tools that allow them to automate processes and maximize their profits, for which reason they stop perceiving valuable economic resources (Gutiérrez, 2010).

However, in recent years and gradually have begun to automate the processes of fish farming (Merino, et al., 2013). The technological tools allow access to information in real time, regardless of distances, which allows saving time and costs and reducing systematic errors (González, et al., 2012). This advantage must be taken advantage of to implement processes that keep updated, real and accurate information on the status of the factors that should be monitored in fish production. Some of these factors are the identification and feeding of the fish, the monitoring of the physical-chemical characteristics of the water and the regulation of the levels of the ponds.

DE ANDA-LÓPEZ, Rosa María, AGUIRRE-ARANDA, Rodolfo, SÁNCHES-SALINAS, Agripín and JARAMILLO-PLATA, Horacio. Intelligent conditioning for the intensive production of tilapia in the southern zone of the State of Mexico. Journal of Natural and Agricultural Sciences. 2019 
The problem is that, they have not been applied to ponds for small producers, where they carry out the work of raising and fattening tilapia in an artisanal way, in many cases in an experimental manner, resulting in serious losses, discouraging the producer and abandoning this work.

According to the literature reviewed several publications and development have been found that aim to control critical variables in the breeding and fattening of fish, but it has only been carried out experimentally or applied to large producers, so it can be seen that the project it is viable, since it will provide an opportunity for technology development with mechatronics students to be able to provide a service to the community, close to them and that as an additional product they are given the opportunity to have system maintenance or improvements according to the observations made.

\section{Methodology}

The study was developed within the facilities of the Technological University of the South of the State of Mexico, located in the southern part of the State of Mexico, in the Municipality of Tejupilco San Miguel Ixtapan, Km. 12 Carretera Tejupilco - Amatepec). Tejupilco (in Nahuatl "Texopilco") is one of the 125 municipalities belonging to the State of Mexico. It has a population of 71,077 inhabitants according to the 2010 population and housing census. Its climate varies from warm to humid and semiwarm humid with rains in summer and with a lower percentage of rains in winter. They vary just like the maximum is $40^{\circ}$ in summer.

The type of study design is of the experimental type, where the variables to be controlled will be the temperature, the $\mathrm{pH}$, the oxygen content and the amount of food, the data collection will be subject to a control over time, since there are proven schedules, in which serious problems can occur when neglecting certain parameters, which causes a high index in the mortality of the fish.

\section{In the first stage, it was designed:}

1. The construction of the most suitable aquaculture facilities, applied to tropical zones. The type of climate present in the south zone of the State of Mexico, mainly subhumid tropical, makes the air conditioning process more difficult, since the humidity and temperature conditions force to generate more robust controls, which ensure the conditioning of the facilities for the fish and the person in charge of the process. The mechanisms that adapt to the needs of the physical conditions of the pond and the fish should be evaluated.

2. Construction and testing of the prototype mechanism at scale. Once the most suitable design has been selected, a test prototype will be built to test its efficiency in terms of dimensions and capacity. It is important to mention that this module will serve as a demonstration prototype to the producers in the area.

3. Development of programming for temperature control, $\mathrm{pH}$, ammonia, water clarity.

4 In this stage of the project was generated in program, using the Arduino platform, to be able to generate and control the variables of temperature, $\mathrm{pH}$, ammonium, water clarity, which are key to ensure the rearing and fattening of the fish, decreasing the presence of diseases or death.

\section{In the second stage of the project was generated:}

5. Design and construction of the most appropriate aeration system, once the control of the variables has been established, the most adequate aeration system will be developed, since it should be ensured that this process allows to set the values established for range. allow the fish a good oxygenation.

6. Design of the water change system, in this section as the pond contemplates that the water is static, it is known that problems are generated by having stagnant water, in addition to containing living beings, their own biological processes cause more pollution in the water, so a replacement should be considered every so often, so that the fish is not stressed, and the variables to be controlled comply with the established ranges and specifications. 
7. Construction of the real working prototype. Since the design was generated, it will go to the stage of building a prototype that meets the specified specifications, likewise it will be provided with solar cells to present a greater autonomy, considering that electricity is not always available in the place of location of the ponds, besides that with this system the laying of cables that can cause an accident will be avoided.

\section{In the third and final phase of the project, it was developed:}

8. Design of the control system, slats and programming. Simultaneously to the development of the mechanical system, the designs and construction of the control system will be developed, it is intended to use the Arduino platform, since it allows to have greater robustness, better response in real time, a simpler programming in routines and a programming platform that allows to change the programming in an agile and efficient way.

9. In this stage the sensors must be placed, $\mathrm{pH}$, ammonium, water clarity, which allow to generate the appropriate bioclimate for the development of the fish for optimum and production.

10. Testing and correction of errors. In this stage of the process the tests will be carried out inside the warehouse to be able to observe if the system complies and respects with the programmed routines, otherwise make the necessary corrections so that the system carries out the process that is required in the estimated time.

For the evaluation of the integrated system in the pond, the following was generated:

- $\quad$ Once the prototype was built, the control system was mounted, using a pond for this purpose, monitoring $24 \mathrm{hrs}$.

- The relevant tests were carried out to verify that the system performs the functions efficiently, complying with the established schedules.

- Its effectiveness was compared to know if it meets the specifications.

\section{Results}

Before beginning the assembly in the test stand, the decision was made to generate a scale prototype pool, model type, using two plastic boxes of $25 \times 40 \mathrm{~cm}$, to simulate the supply and control of the water pumps, and the second to control the $\mathrm{PH}$ measurement process, amount of water, aeration, water clarity and temperature, where a key is placed to simulate disturbances in the system. Figure 1 shows the process to make the model of the experimental pool.

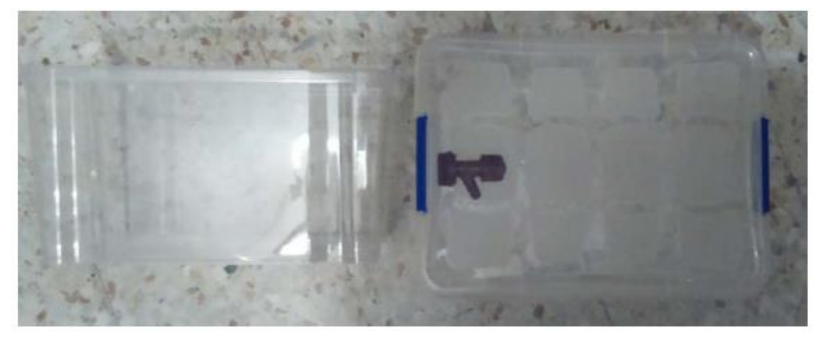

Figure 1 Plastic boxes for experimental model Source: Own authorship

As a second point, the optimal working values are established, where fattening and growth of the tilapia are favored, these are shown in the following table, table 1.

\begin{tabular}{|l|l|}
\hline \multicolumn{1}{|c|}{ Parameter } & \multicolumn{1}{c|}{ Value } \\
\hline Temperature & $28^{\circ} \mathrm{C} \mathrm{a} 30^{\circ} \mathrm{C}$ \\
\hline $\mathrm{pH}$ & $6.5 \mathrm{a} 9$ \\
\hline Dissolved oxygen & $2 \mathrm{a} 3 \mathrm{mg} / 1$ \\
\hline Salinity & $24 \mathrm{ppt}$ \\
\hline Turbidity & $30 \mathrm{~cm}$ of visibility \\
\hline
\end{tabular}

Table 1 Optimum culture values for Oreochromis niloticus (nile tilapia)

With these values, the different control systems were designed, beginning with the water level (figure 2), the pond purifier (aeration) (figure 3), $\mathrm{pH}$ (figure 4), temperature (figure 5), since they are the variables to be manipulated to obtain the control system of the pool, to generate the suitable bioclimate for growth and fattening of the tilapia. 


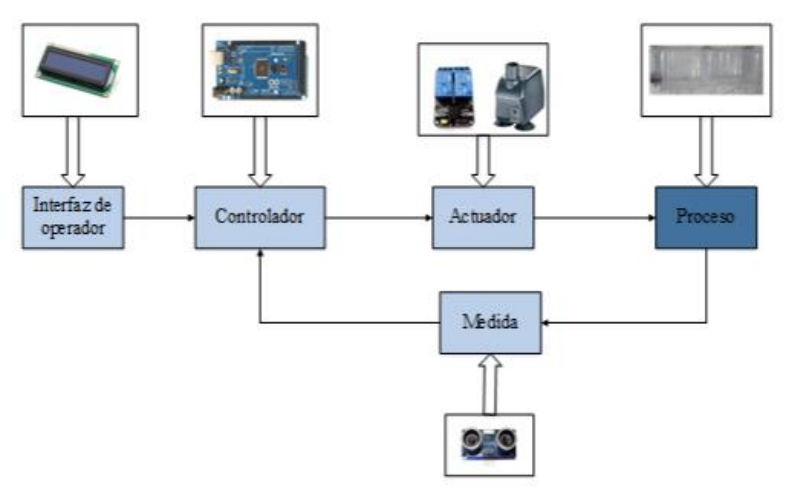

Figure 2 Water level control scheme

Source: Own Authorship

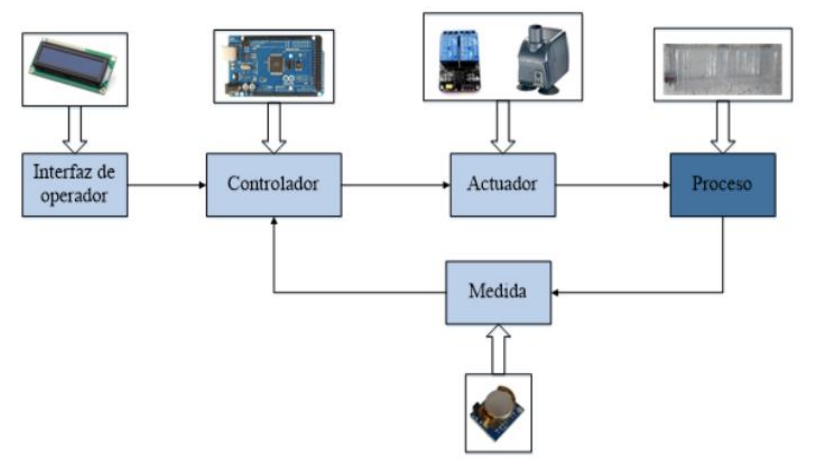

Figure 3 Control scheme for aeration

Source: Own authorship

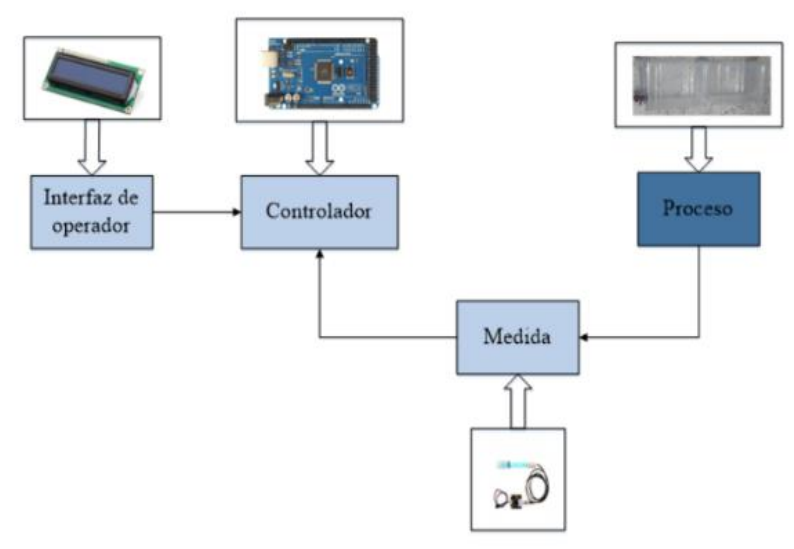

Figure 4 Control scheme for $\mathrm{Ph}$

Source: Own authorship

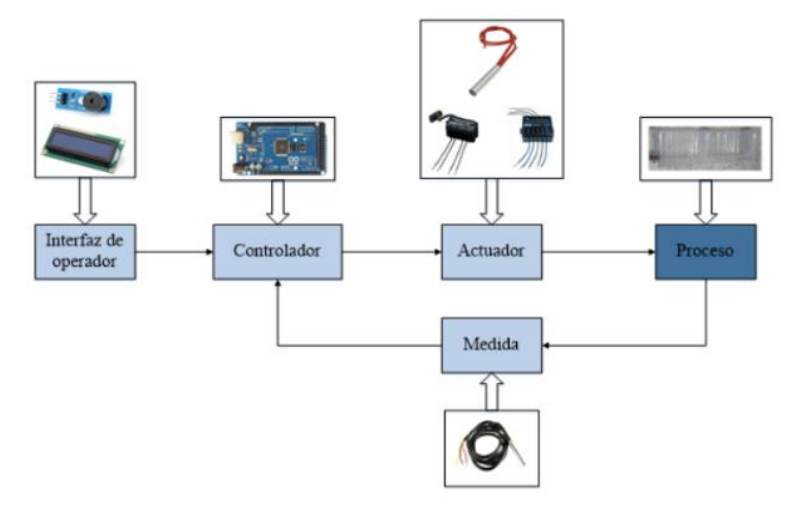

Figure 5 Temperature control scheme Source: Own authorship
In figure 6 , the connection diagram of the system in general is shown, where a lamp for the internal control of the pool is attached, to perform cleaning or disinfection and maintenance work in general to pipes and bubbler, since by normalization, tilapia does not develop under normal light at $100 \%$, the water must have a certain degree of turbidity $(30 \mathrm{~cm})$, so the use of lighting is necessary and would not be used, only for special work circumstances, situation that would not bother the fish.

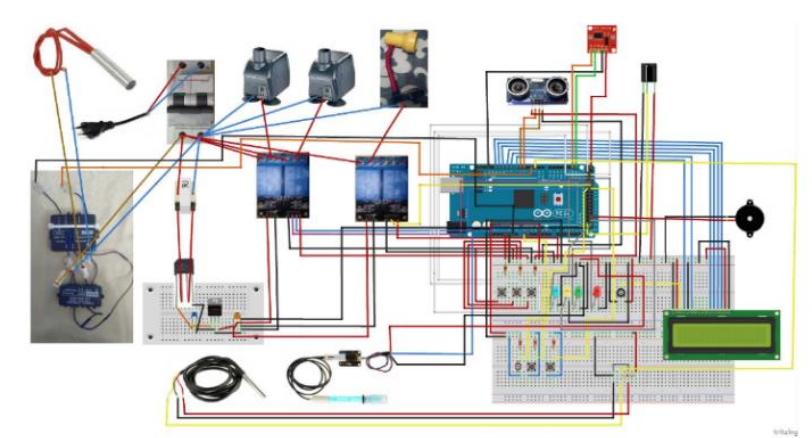

Figure 6 General system wiring scheme Source: Own authorship

\section{Level sensor}

The water level control of the pool is formed by an ultrasonic sensor that measures the distance at which the water is located, and through several calculations made by the Arduino board, the water level is obtained. In this section you will see to what extent the value measured by the system is true. This will be done by measuring with a ruler and with the control system, the level of water before different SP inputs or desired values, thus obtaining the results of the actual value, the measured value and the measurement error. Table 2 is shown below with the results obtained:

\begin{tabular}{|c|c|c|c|}
\hline $\begin{array}{l}\text { SP or set } \\
\text { point }(\mathrm{cm})\end{array}$ & $\begin{array}{l}\text { Measured } \\
\text { value } \\
(\mathrm{cm})\end{array}$ & $\begin{array}{l}\text { Real } \\
\text { value } \\
(\mathrm{cm})\end{array}$ & $\begin{array}{l}\text { Measurement } \\
\text { error }(\mathbf{c m})\end{array}$ \\
\hline 5 & 4 & 5.5 & 0.5 \\
\hline 8 & 7 & 8.5 & 0.5 \\
\hline 11 & 10 & 11.5 & 0.5 \\
\hline 14 & 13 & 14.5 & 0.5 \\
\hline
\end{tabular}

Table 2 Results obtained from the level sensor at different heights

Source: Own authorship

The SP or set point level value can be changed at any time by the user from the LCD screen, in figure 7 the measurement process is observed. 


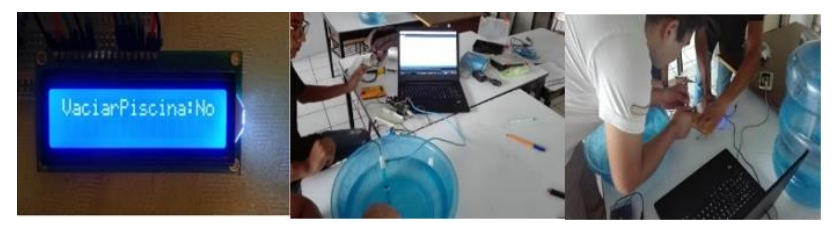

Figure 7 Wiring and level sensor display Source: Own authorship

\section{Debug sensor}

For the results of the control of the pool treatment plant, tests have been carried out with different activation hours and with different operating times, obtaining good results in all tests. It is possible to say that with the passage of time the clock module can be outdated in time, causing the system to be activated sooner or later, this implies that the date and time of the device must be reprogrammed, the times were achieved with the experience of the producers, since they indicate the time of replacement of water and the time for aeration, which allowed to program the clock, still needs improvement, this process is shown in Figure 8.

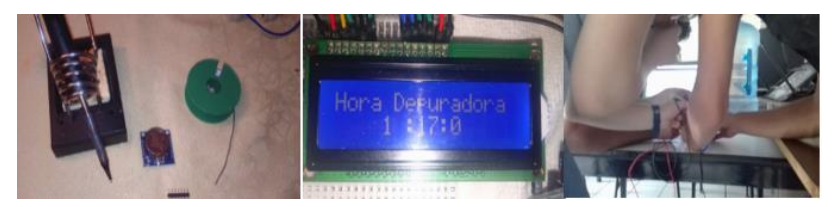

Figure 8 Connection and testing with the DS1307 watch Source: Own authorship

\section{PH sensor}

For the results of the PH measurement system, tests have been carried out with different liquids, such as water, milk and coke, to ensure the proper functioning of the system and the calibration of the sensor, Table 3 shows the results obtained.

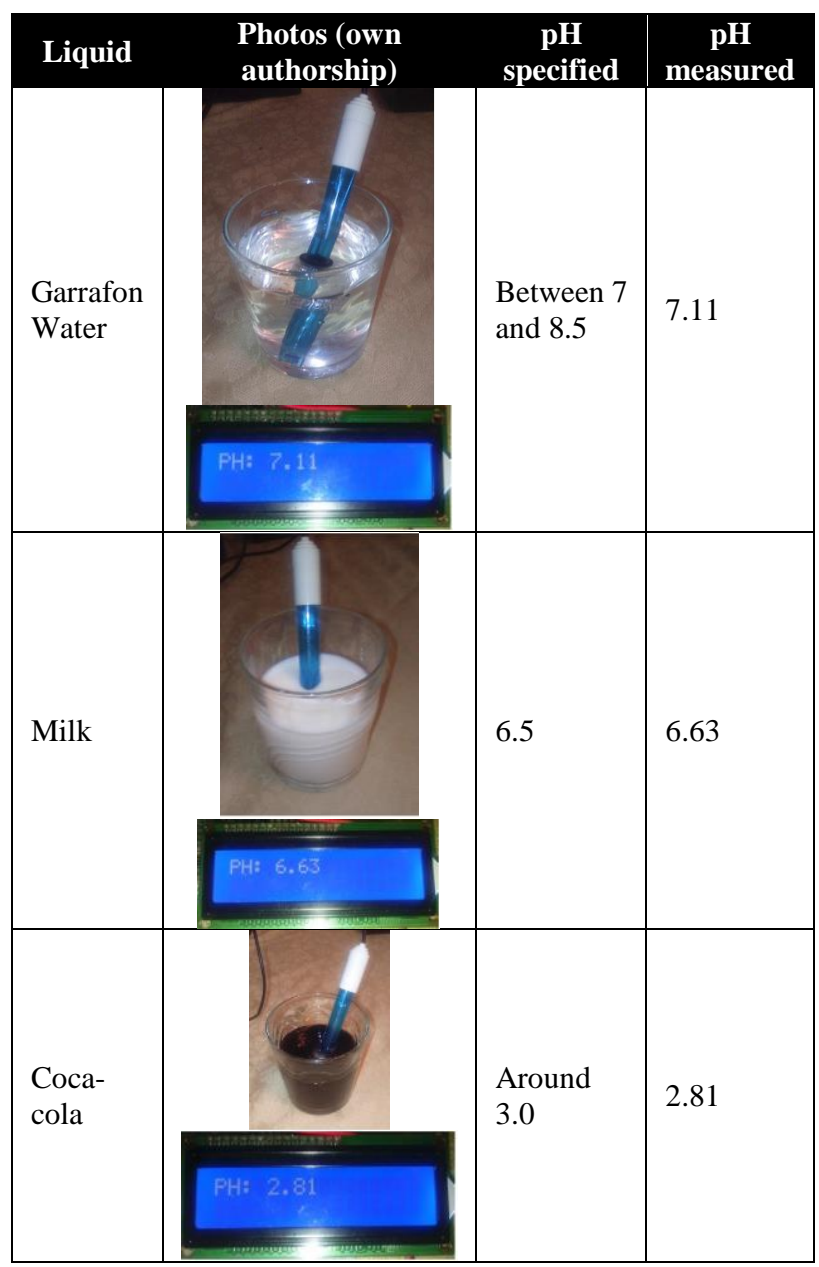

Tabla 3 Resultados obtenidos de la pruebas con el sensor $\mathrm{PH}$

Source: Own authorship

Given the results obtained in the previous measurement tests, we can say that the measurement system works properly and that the $\mathrm{pH}$ sensor is well calibrated, so it is assembled in the model, as shown in Figure 9.

\section{Conclusions}

CAMAZAMA is a technological development of agricultural engineering, which will begin the process of modernization of the work of the field, is considered to be a detonator so that other areas of opportunity, allowing to identify technology agricultural automation is gradually enter in the southern region of the State of Mexico. 


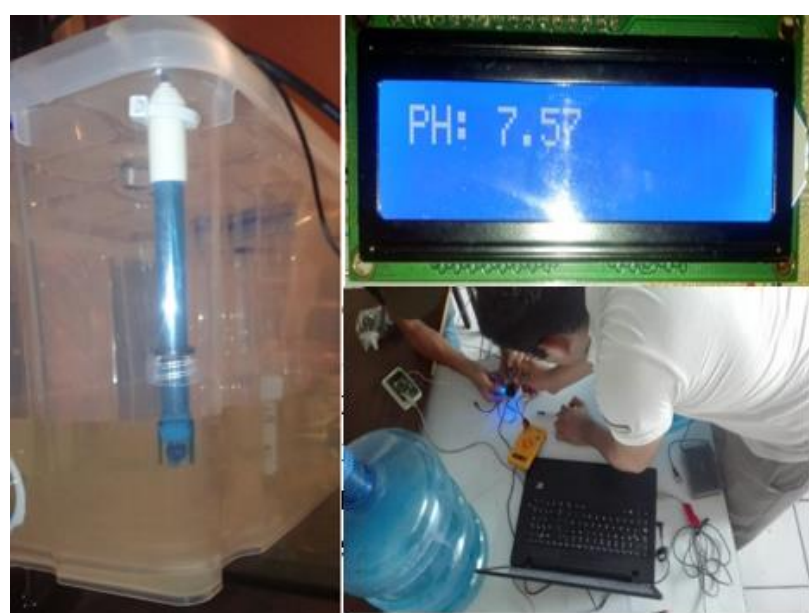

Figure 9 Assembly and testing with $\mathrm{PH}$ sensor (selfauthoring)

\section{Temperature sensor}

In the temperature control of the water in the heated pool, two types of tests have been carried out, one of measurement to see if the temperature measured by the DS18B20 temperature sensor matches that of a more accurate SIEMENS digital thermostat, thus ensuring the sensor operation, and another test by changing the SP or desired value of the control to observe the results and behavior of the system. The following temperatures have been obtained in the measurement test. $26.87^{\circ} \mathrm{C}$ of the DS18B20 temperature sensor and $27^{\circ} \mathrm{C}$ of the thermostat, the components are shown in Figure 10.

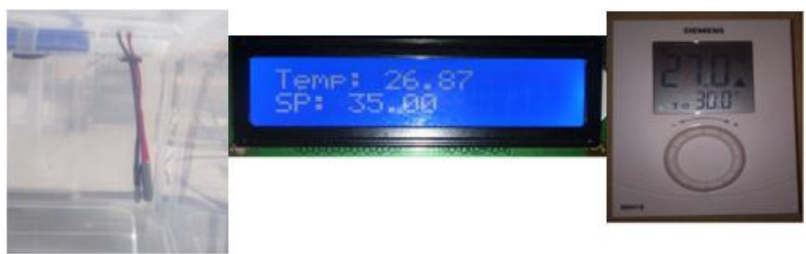

Figure 10 Installation of the DS18B20 temperature sensor and the heating resistance and comparing with the SIEMENS thermostat (self-authoring)

As for the water temperature control tests, two SPs, $28^{\circ} \mathrm{C}$ and $30^{\circ} \mathrm{C}$ have been selected. Two graphs are shown below, one for $31^{\circ} \mathrm{C}$ and one for $32^{\circ} \mathrm{C}$.

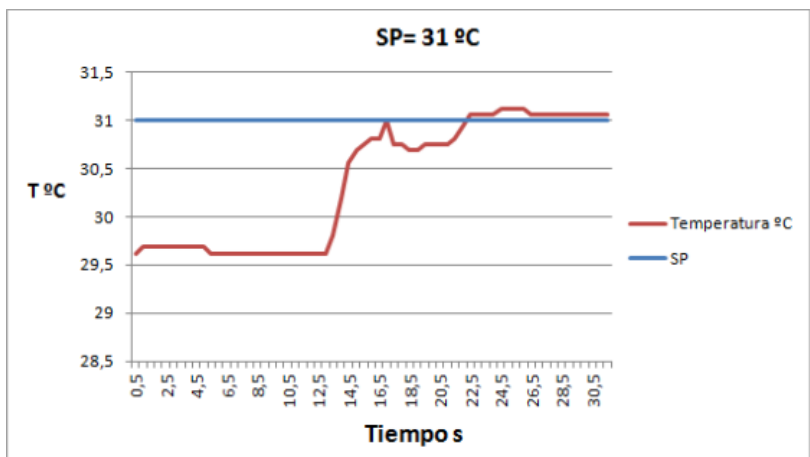

Figure 11 Graphic temperature control test I (selfauthoring)

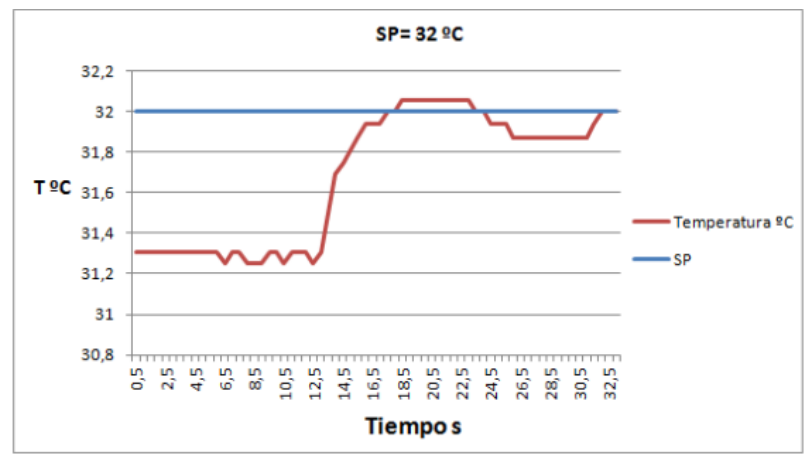

Figure 12 Graphic temperature control test II (selfauthoring)

Looking at the graphs shown in Figure 11 and 12, it can be said that the temperature control of the water in the heated pool works correctly because the water temperature reaches the SP or desired value in a short time, also because it has selected a SP or desired value of a degree centigrade more than the measured water temperature, and that when the water temperature reaches the SP, the temperature remains stable. Figure 13 shows the connections of the elements that are integrated into the system in general.

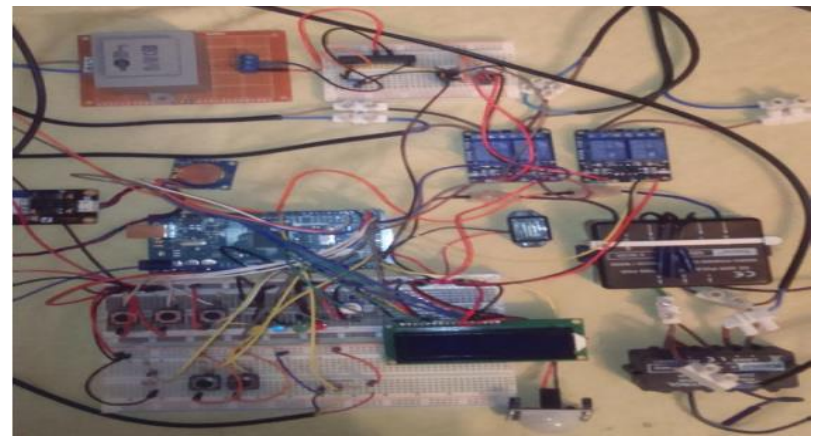

Figure 13 Control system connection (self-authoring) 


\section{Conclusions}

It is important to mention that the proposed stages have been fulfilled, some details being found during the development, for example at the time of putting into operation the water level control system of the pool a problem occurred. When one of the water pumps was activated, the LCD screen was turned off or rare characters appeared that prevented control of the system and view the information offered by the LCD screen. After looking for information on the problem, it was found that this was due to the fact that when activating any of the water pumps through the relays, an electrical noise was produced that the Arduino Mega2560 board electronics could not cope with, this problem was He resolved by building a $5 \mathrm{Vdc}$ power supply to power the relays.

Another serious problem that arose was when doing certain tests with the DS1307 clock module, the date 2000/1/1 0: 0: 0 was always shown on the LCD. The problem mentioned above in the last section was due to the fact that the date and time was not set before starting to program using the clock module.

The development of the project has allowed to open doors with the link between producers in the area and the University, since due to the measurements that are made to be able to know if the sensors work well under certain working conditions, the permanent measurement of the $\mathrm{PH}$ in a tilapia pond, so that process is being implemented, as it is a single sensor the programming procedure is simpler, but the problem arose that you have to clean the sensor more often, if it is required to ensure measurements, so work is being done to measure the time in which the sensor would initiate the presence of faults.

This development allows more interaction with society, observing more problems and needs that the area can support to solve or improve conditions. In particular the present project is leaving a great accumulation of experiences and knowledge, and although it is working with a model, it is being understood that the project can be scaled up and applied to real productive processes. Situation that opens the possibilities of continuing and selling the system.
At the moment the system works without fish, and is a prototype to scale, it is being negotiated with a producer in the area to allow the system to be mounted in a pond to start monitoring the variables already with the fish and with the conditioning which is proposed, since it is intended to isolate the pond from the weather, so that a bioclimate can be generated inside that further benefits the production of tilapia.

\section{Acknowledgement}

To the COMECYT, for providing support in the realization of the present research. We thank the University technological of the South of the State of Mexico for the support provided for the development of the prototype shows.

\section{References}

Amador del Ángel, L. E.; Córdoba Rivera, C. M.; Gómez Vázquez, J.; Villareal López, C.; Valdez Morales, S. \& Cabrera Rodríguez, P. (2006). Diagnóstico de las unidades femeniles de producción rural (UFPR) de Mojarra Tilapia (Oreochromis spp) en la Península de Atasta, Campeche (México). Comunicación Científica - CIVA 2006. 907-915. [en línea]. Disponible desde: http://www.civa2006.org. Fecha de última consulta: 15/01/2018.

Merino, M. C.; Bonilla, S. P. y Bages, F. (2013). Diagnóstico del estado de la acuicultura en Colombia. Bogotá: Autoridad Nacional de Acuicultura y Pesca AUNAP.

Edwards, P. \& Demaine ,H. (1997). Rural aquaculture: Overview and framework for country reviews. RAP Publ. 1997/36. RAP FAO Bangkok.

Esquivel, M. A.; Merino, M. C.; Restrepo, J. J.; Narváez, A.; Polo, C.; Plata, J. y Puentes, V. (2014). Estado de la pesca y la acuicultura 2014. Bogotá: Autoridad Nacional de Acuicultura y Pesca AUNAP.

García Calderón, J. L., Cabrera Jiménez, J.A. (1990). La acuicultura. Definición y Límites. Instituto de Biología. México.

González Coneo, J.; Nuñez, Pérez, B. y Viloria Molinares, P. (2012). Sistema de monitoreo en tiempo real para la medición de temperatura, Scientia et Technica, 50 (17). pp. 128-131. 
Gutiérrez, F. d. P. (2010). Los recursos hidrobiológicos y pesqueros continentales en Colombia. Bogotá: Institución de Investigación de Recursos Biológicos Alexander von Humboldt.

FAO, 2002, Informe de la Reunión ad hoc de la Comisión de Pesca Continental para América Latina sobre la expansión de los diferentes tipos de acuicultura rural en pequeñas escala como parte del desarrollo rural sostenido. FAO, Informe de Pesca N ${ }^{\circ} 694$ RLC/FIRI/R694 (Es) ISSN 1014-6547 Panamá, República de Panamá, 21-24 de mayo 2002.

Lagos, Darío \& Mera, Zamir. (2015). Sistema automatizado alimentado con energía fotovoltaica para el control de nivel y recambios de agua en estanques destinados al cultivo de tilapia mejorando la sanidad acuícola. Informe técnico. Universidad Técnica del Norte. Facultad de ingeniería en ciencias aplicadas carrera de Ingeniería en Mecatrónica. Ibarra, Ecuador.

Ponce Palafox, J. T.; Romero Cruz, O.; Castillo Vargasmachuca, S.; Arteaga Nochebuena, P.; Ulloa García, M.; González Sala, R.; Febrero Toussaint, I. \& Esparza Leal, H. (2006). El desarrollo sostenible de la acuicultura en América Latina. Revista Electrónica de Veterinaria REDVET. Vol. VII, $\mathrm{n}^{\mathbf{0}}$ 07, Julio/2006, [en línea]. Disponible en http://www.veterinaria.org/revistas/redvet/n070 706.html. Fecha última consulta: 02/02/18.

SEMARNAP. (2007). Anuario estadístico de pesca. Secretaría de Medio Ambiente Recursos Naturales y Pesca. México. 230 pp. 